\title{
PENINGKATAN HASIL BELAJAR SISWA KELAS IV MELALUI METODE TUTOR SEBAYA PADA MATA PELAJARAN BAHASA INDONESIA SDN 165732 KOTA TEBING TINGGI.
}

\author{
Sri Susilowati \\ Surel: Susilosri868@gmail.com
}

\begin{abstract}
The purpose of this study was to find out the learning outcomes of Indonesian Language class IV SD Negeri 165732 Tebing Tinggi City. The type of research conducted is classroom action research. The action given is implementation through the Peer Tutor Method. As the subjects in this study were Grade IV students of SD Negeri 165732 in Tebing Tinggi City, amounting to 36 people consisting of 15 male students and 21 female students. This research is planned to be held in the first semester of the 2018/2019 academic year. The results of observational cycle 1 and cycle 2 experienced an increase in cycle 1, the number of active students $55.60 \%$ rose to $90.60 \%$ in cycle 2, the process skills in cycle 1 were $50.00 \%$ up to 88.90 in cycle 2 , the number students who complete from $27.22 \%$ to $94.44 \%$ in cycle 2, the average value in cycle 1 is: 58.33 up to 73.90 in cycle 2.
\end{abstract}

Keywords: Learning outcomes, peer tutors, Indonesian

\begin{abstract}
ABSTRAK
Tujuan penelitian ini adalah untuk Mengetahui hasil belajar Bahasa Indonesia siswa kelas IV SD Negeri 165732 Kota Tebing Tinggi. Jenis penelitian yang dilaksanakan adalah penelitian tindakan kelas. Tindakan yang diberikan adalah penerapan melalui Metode Tutor Sebaya. Sebagai subjek pada penelitian ini adalah siswa kelas IV SD Negeri 165732 Kota Tebing Tinggi yang berjumlah 36 0rang terdiri dari 15 Orang siswa laki laki dan 21 orang siswa perempuan. Penelitian ini direncanakan akan dilaksanakan pada semester 1 tahun pelajaran 2018/2019. Hasil penelitian pengamatan siklus 1 dan siklus 2 mengalami peningkatan pada siklus 1 jumlah siswa yang aktif 55,60\% naik menjadi 90,60 \% pada siklus 2 ,keterampilan proses pada siklus 1adalah $50,00 \%$ naik menjadi 88,90 pada siklus 2,jumlah siswa yang tuntasnaik dari $27,22 \%$ menjadi $94,44 \%$ pada siklus 2,nilai rata-rata pada siklus 1 adalah: 58,33 naik menjadi 73,90 pada siklus 2 .
\end{abstract}

Kata Kunci : Hasil belajar, Tutor sebaya, Bahasa Indonesia

\section{PENDAHULUAN}

Bahasa memiliki peran sentral dalam perkembangan intelektual, sosial, dan emosional peserta didik dan merupakan penunjang keberhasilan dalam mempelajari semua bidang studi. Pembelajaran bahasa Indonesia diarahkan untuk meningkatkan kemampuan peserta didik untuk berkomunikasi dalam bahasa Indonesia dengan baik dan benar, baik secara lisan maupun tulis. Berdasarkan uraian pada latar belakang di atas, dapat diidentifikasikan yaitu beberapa permasalahan sebagai berikut:

a. Motivasi belajar bahasa Indonesia siswa masih rendah 
Sri Susilowati: Peningkatan Hasil Belajar Siswa...

b. Siswa kurang menghargai pentingnya pelajaran bahasa Indonesia

c. Sebagian besar siswa tidak aktif dalam belajar

d. Siswa malu bertanya pada guru, walaupun belum paham dengan materi yang diterangkan guru

e. Hasil belajar bahasa Indonesia siswa masih rendah.

Tujuan penelitian ini adalah untuk: Mengungkapkan aktivitas belajar Bahasa Indonesia siswa kelas kelas IV SD Negeri 165732 Kota tebing Tinggi, Mengetahui hasil belajar Bahasa Indonesia siswa kelas IV SD Negeri 165732 Kota Tebing Tinggi.

\section{METODE PENELITIAN}

$\begin{array}{cl}\text { Jenis } & \text { penelitian } \begin{array}{r}\text { yang } \\ \text { dilaksanakan adalah penelitian }\end{array}\end{array}$ tindakan kelas. Tindakan yang diberikan adalah penerapan melalui Metode Tutor Sebaya (PeerTutor).

Sebagai subjek pada penelitian ini adalah siswa kelas IV SD Negeri 165732 Kota Tebing Tinggi yang berjumlah 36 Orang terdiri dari 15 Orang siswa laki-laki dan 21 orang siswa perempuan.

Prosedur penelitian yang digunakan dalam penelitian ini adalah model siklus yang melalui empat tahap yaitu: Perencanaan (Planning), tindakan (Action), observasi (Observation) dan refleksi (Reflection).

Kegiatan yang dilakukan pada tahap perencanaan sebagai berikut : Merancang pembentukan kelompok berpasangan yang terdiri dari 4 orang siswa,secara homogen Pembentukan kelompok didasarkan pada kemampuan akademik dan memperhatikan jenis kelamin.

Setelah perencanaan disusun, maka langkah selanjutnya adalah melaksanakan rencana tersebut kedalam bentuk tindakan. Pada penelitian ini, tahap tindakan yang akan dilaksanakan dalam kegiatan pembelajaran Metode Tutor Sebaya.

Tahap observasi adalah melakukan pengamatan terhadap efek dari tindakan yang diberikan untuk melihat dan mendokumentasikan pengaruhpengaruh yang diakibatkan oleh tindakan tersebut. Pengamatan dilakukan terhadap aktivitas siswa selama pembelajaran berlangsung yang meliputi keaktifan.

Tahap refleksi ini bertujuan untuk memberikan informasi mengenai proses pembelajaran dengan Metode Tutor Sebaya (PEER TOTOR).

Teknik pengumpulan data yang digunakan dalam penelitian ini adalah melalui pengamatan dengan mengisi lembar observasi, angket dan pemberian tes hasil belajar.

a. Untuk mengetahui aktivitas siswa selama proses pembelajaran berlangsung, digunakan lembar observasi yang meliputi aktivitas siswa pada saat guru menyampaikan informasi. 
b. Pemberian angket bertujuan untuk mendapatkan informasi tentang sikap siswa terhadap pembelajaran Bahasa Indonesia dengan menggunakan Metode Tutor Sebaya (PEER TOTOR) angket diberikan di akhir siklus.

c. Tes hasil belajar digunakan untuk mengetahui peningkatan hasil belajar setelah berlangsung proses pembelajaran. Tes yang dimaksud adalah tes hasil belajar yang menyangkut ranah kognitif yang diadakan pada akhir siklus.

Teknik analisis data yang digunakan adalah :

Untuk data aktivitas siswa diolah secara kuantitatif dengan menghitung persentasenya, dengan menggunakan rumus yang dikemukakan oleh Anas Sudijono (1997) sebagai berikut :

$$
P=\frac{F}{N} x 100 \%
$$

Keterangan :

$\mathrm{P}=$ Presentase

$\mathrm{F}=$ Frekuensi aktivitas belajar siswa

$\mathrm{N}=$ Jumlah siswa seluruhnya

Selanjutnya berdasarkan prosentase yang diperoleh, maka kriteria aktivitas siswa menurut Dimyati dan Mudjiono (2006:125) sebagai berikut :

$$
\begin{array}{cll}
1-25 \% & : & \text { Sedikit sekali } \\
26-50 \% & : & \text { Sedikit } \\
51-75 \% & : & \text { Banyak } \\
76-99 \% & : & \text { Banyak sekali }
\end{array}
$$

Untuk data sikap siswa yang diperoleh dari lembar kuesioner (angket) dianalisis dengan menggunakan rumus yang dikemukakan oleh Nana Sudjana (1995) yaitu :

$$
P=\frac{f}{N} x 100 \%
$$

Keterangan :

$\mathrm{P}=$ Angka Presentase

$\mathrm{f}=$ Frekuensi Jawaban

$\mathrm{N}=$ Jumlah Responden

Dikatakan seorang siswa tuntas belajar apabila mencapai nilai ketuntasan/tingkat penguasaan minimal yang ideal yaitu \% (Depdiknas, 2004). Untuk kelas IV SD Negeri 165732 Kota Tebing Tinggi Nilai Kriteria Ketuntasan Minimal (KKM) untuk pelajaran Bahasa Indonesia yang telah ditetapkan adalah $70 \%$.Tingkat penguasaan hasil belajar dapat dihitung dengan menggunakan rumus sebagai berikut :

$$
N I=\frac{T}{S M} x 100 \%
$$

Keterangan :

$N I=$ Ketuntasan Belajar Individu

$T=$ Skor Yang Diperoleh Siswa

$S M=$ Skor Maksimum Tes 
Sri Susilowati: Peningkatan Hasil Belajar Siswa...

$\begin{array}{lllll}\text { HASIL PENELITIAN } & \text { DAN } & \text { pembelajaran Metode Tutor Sebaya } \\ \text { PEMBAHASAN } & & \text { dengan } & \text { menggunakan } & \text { bantuan } \\ \text { Pembelajaran yang dilaksanakan } & \text { Lembar } & \text { Kerja Siswa } & \text { (LKS). } \\ \text { adalah meggunakan } \quad \text { model } & & & & \end{array}$

Tabel 1. keaktifan siswa siklus 1

\begin{tabular}{c|l|c|c}
\hline No & \multicolumn{1}{|c|}{ Keaktifan } & Jumlah siswa & \% \\
\hline 1. & Aktif bertanya & 13 & $36,11 \%$ \\
2. & Aktif diskusi & 20 & $55,60 \%$ \\
3. & Aktif menjawab & 10 & $27,22 \%$ \\
4. & Aktif mengerjakan tugas & 28 & $77,78 \%$ \\
& & & \\
\hline & Rata rata & & $\mathbf{4 9 , 1 8 \%}$ \\
\hline
\end{tabular}

Tabel 2. Skor keaktifan Individu siklus 1

\begin{tabular}{l|l|c|c|c}
\hline No & \multicolumn{1}{|c|}{$\begin{array}{c}\text { Katagori } \\
\text { keaktifan }\end{array}$} & Skor & $\begin{array}{c}\text { Jumlah } \\
\text { siswa }\end{array}$ & $\%$ \\
\hline 1. & Aktif & 4 & 10 & $27,78 \%$ \\
2. & Cukup aktif & 3 & 14 & $38,90 \%$ \\
3. & Kurang aktif & 2 & 12 & $33,33 \%$ \\
4. & Tidak aktif & 1 & 2 & $55,60 \%$ \\
\hline
\end{tabular}

Tabel 3. Keterampilan Proses Siklus 1

\begin{tabular}{c|l|c|c}
\hline No & \multicolumn{1}{|c|}{ Katagori Keterampilan } & Jumlah siswa & $\%$ \\
& & & \\
\hline 1 & Terampil menyiapakan tugas & 15 & $69,44 \%$ \\
2 & Terampil mengerjakan soal & 11 & $30,56 \%$ \\
3 & Terampil memecahkan masalah & 14 & $38,89 \%$ \\
& Terampil bekerja sama & & \\
4 & Terampil beradaptasi dengan & 25 & $69,44 \%$ \\
5 & teman & 23 & $63,89 \%$ \\
& Terampil mengambil & & $50 \%$ \\
\hline 6 & kesimpulan & 18 & $\mathbf{5 3 , 7 0 \%}$ \\
\hline
\end{tabular}

Tabel 4. Skor Keterampilan Individu Siklus 1

\begin{tabular}{clccc}
\hline No & $\begin{array}{c}\text { Katagori } \\
\text { keterampilan }\end{array}$ & Skor & $\begin{array}{c}\text { Jumlah } \\
\text { siswa }\end{array}$ & $\%$ \\
\hline 1. & Terampil & 5,6 & 8 & $22,22 \%$ \\
2. & Cukup terampil & 4 & 13 & $36,11 \%$ \\
3. & Kurang terampil & 3 & 10 & $27,78 \%$ \\
4. & Tidak terampil & 1,2 & 5 & $13,90 \%$ \\
\hline
\end{tabular}


Tabel 5. Hasil Belajar Siswa Siklus 1

\begin{tabular}{lcccc}
\hline $\begin{array}{c}\text { Jumlah } \\
\text { siswa }\end{array}$ & $\begin{array}{c}\text { Nilai } \\
\text { rata-rata }\end{array}$ & $\begin{array}{c}\text { Hasil } \\
\text { Nilai }>=70\end{array}$ & $\begin{array}{c}\text { Hasil } \\
\text { nilai }< \\
\mathbf{7 0}\end{array}$ & $\begin{array}{c}\text { Nilai yang } \\
\text { tuntas \% }\end{array}$ \\
\hline 36 & 58,33 & 10 & 26 & $27,78 \%$ \\
\hline
\end{tabular}

Tabel 6. hasil pengamatan siklus 1

\begin{tabular}{clccc}
\hline No & \multicolumn{1}{c}{ Variabel } & $\begin{array}{c}\% \\
\text { tuntas }\end{array}$ & $\begin{array}{c}\text { \% tidak } \\
\text { tuntas }\end{array}$ & $\begin{array}{c}\text { Indikator } \\
\text { kebrhasilan }\end{array}$ \\
\hline 1. & Keaktifan & $55,60 \%$ & $44,40 \%$ & $70,00 \%$ \\
2. & Keterampilan & $50,00 \%$ & $50,00 \%$ & $70,00 \%$ \\
3. & Hasil belajar & $27.22 \%$ & $72,78 \%$ & $70,00 \%$ \\
\hline
\end{tabular}

\section{Pembahasan}

Siklus 2 pada hakekatnya meninjau kembali rancangan pembelajaran yang disiapkan untuk siklus 1. Disini benar-benar dipersiapkan lebih terarah pada indikator pencapaian. Penekanan padan kemamapuan individu untuk berperan aktif dalam pembelajaran. Meninjau lebih detail tentang indikator keaktifan siswa, mempersiapkan bantuan lebih khusus pada siswa-siswa yang sebelum kelihatan aktif baik dalam proses pembelajaran maupun sebagai tutor sebaya.

Hasil pengamatan pada siklus 1 pada varibel-variabel antara lain keaktifan siswa, ketrampilan bermain peran dalam tutor sebaya dan hasil belajar menunjukkan hasil sebagai berikut

Tabel 7. Keatifan Siklus 2

\begin{tabular}{c|l|c|c}
\hline No & Keaktifan & Jlh siswa & \% \\
\hline 1. & bertanya & 28 & $77,78 \%$ \\
2. & diskusi & 30 & $83,33 \%$ \\
3. & menjawab & 27 & $75,00 \%$ \\
4. & mengerjakan tugas & 36 & $100 \%$ \\
& & & $\mathbf{8 4 , 0 2 \%}$ \\
\hline
\end{tabular}

Dari pengamatan peneliti terhadap keaktifan dengan kriteria aktif bertanya, diskusi, menjawab pertanyaan dan mengerjakan tugas pada siklus 2 ini, peneliti menilai keatifan siswa sudah mengalami kemajuan, sehingga yang aktif bertanya sekarang menjadi 28 orang siswa $(77,78 \%)$ atau ada kenaikan 18 orang siswa, berdiskusi 30 orang $(83,33 \%)$ atau ada kenaikan 16 orang siswa, aktif menjawab pertanyaan guru 27 orang siswa $(75,00 \%)$ atau ada kenaikan 15 orang siswa, sedang aktif mengerjakan tugas 36 orang siswa $(100 \%)$. 
Sri Susilowati: Peningkatan Hasil Belajar Siswa...

Tabel 8. Keaktifan Individu Siklus 2

\begin{tabular}{llccc}
\hline No & $\begin{array}{c}\text { Katagori } \\
\text { keaktifan }\end{array}$ & Skor & $\begin{array}{c}\text { Jumlah } \\
\text { siswa }\end{array}$ & $\%$ \\
\hline 1. & Cukup & 4 & 24 & $66,67 \%$ \\
2. & Kurang & 3 & 9 & $25,00 \%$ \\
3. & Tidak aktif & 2 & 2 & $5,60 \%$ \\
4. & & 1 & 1 & $2,78 \%$ \\
\hline
\end{tabular}

Dilihat dari keatifan individu yang mendapat skor 4 atau katagori aktif di semua kriteria keatifan ada 24 orang siswa $(66,67 \%)$ ada penambahan 14 orang siswa yang mendapat skor 3 atau katagori cukup aktif sebanyak 9 orang siswa $(25,00 \%)$ ada penurunan 5 orang siswa yang, mendapat skor 2 dengan katagori kurang baik sebanyak 2 orang siswa $(5,60 \%)$ ada penurunan
10 orang siswa dan yang mendapat skor 1 1dengan katagori tidak aktif ada 1 orang siswa $(2,78 \%)$ ada penurunan 1orang siswa. Rata-rata keaktifans iswa dalam siklus 2 adalah 84,02 \% dan siswa yang mendapat skor $>=3$ ada( $91,67 \%)$ hasil ini sudah melampui indicator pencapaian yang ditarget rata-rata keaktifan siswa $70 \%$ dan siswa yang mendapat skor $<=3$ ada $70 \%$.

Tabel 9. Keterampilan Proses Siklus 2

\begin{tabular}{llll}
\hline No & \multicolumn{1}{c}{ Katagori Keterampilan } & $\begin{array}{c}\text { Juml } \\
\text { ah } \\
\text { siswa }\end{array}$ & $\begin{array}{c}\text { Persentase } \\
\mathbf{\%}\end{array}$ \\
\hline 1 & Terampil menyiapakan tugas & 29 & $80,60 \%$ \\
2. & Terampil mengerjakan soal & 32 & $88,90 \%$ \\
3. & Terampil memecahkan masalah & 30 & $83,33 \%$ \\
4. & Terampil bekerja sama & 32 & $88,90 \%$ \\
5. & Terampil beradaptasi dengan teman & 36 & $100 \%$ \\
6. & Terampil mengambil kesimpulan & 33 & $91,67 \%$ \\
\hline \multicolumn{3}{l}{ Rata-rata } \\
\hline
\end{tabular}

Dari pengamatan peneliti terhadap keterampilan siswa dengan terampil menyiapkan tugas bekerja sama, beradaptasi, dengan teman dan mengambil keputusan kesimpulan peneliti menilai juga ada kenaiakan yang berarti, hal ini dapat dilihat dari hasil pengamatan siklus 2. Siswa yang terampil menyiapkan tugas sebanyak 29 orang siswa $(90,60 \%)$ ada kenaikan 14 Orang siswa, terampil mengerjakan soal sebanyak 32 orang siswa $(88,90 \%)$ ada kenaikan 21 orang siswa siswa yang terampil memecahkan masalah sebanyak 30 orang siswa $(83,33 \%)$ ada kenaikan 17 orang siswa, siswa yang trampil bekerja sama sebanyak 32 orang siswa $(88,90 \%)$ ada kenaikan 7 orang siswa ,siswa yang terampil beradaptasi dengan teman sebanyak 36 orang siswa (100\%) ada kenaikan 13 orang siswa dan terampil mengambil keputusan 34 orang siswa $(94,44 \%)$ ada kenaikan 16

siswa. 
Tabel 10. Keterampilan Individu Siklus 2

\begin{tabular}{llccc}
\hline No & $\begin{array}{c}\text { Katagori } \\
\text { keterampilan }\end{array}$ & Skor & $\begin{array}{c}\text { Jumla } \\
\text { h siswa }\end{array}$ & $\%$ \\
\hline 1. & Terampil & 5 dan 6 & 24 & $66,67 \%$ \\
2. & Cukup terampil & 4 & 9 & $25,00 \%$ \\
3. & Kurang & 3 & 2 & $5,56 \%$ \\
4. & terampil & 1 dan 2 & 1 & $2,78 \%$ \\
& Tidak terampil & & & \\
\hline
\end{tabular}

Dilihat dari keterampilan Individu yang mendapat skor $>=5$ dan 6 dengan katagori terampil ada 24 orang siswa $(66,67 \%)$, ada kenaikan 16 orang siswa, yang mendapat skor 4 dengan katagori cukup terampil ada 9 orang siswa, $(25,00 \%)$, ada kenaikan 8 orang siswa, mendapat skor 3 dengan katagori kurang terampil 10 orang siswa $(5,56 \%)$, ada penurunan 8 orang siswa dan yang mendapat skor 1 dan 2 dengan katagori tidak terampil ada 1 orang
Siswa $(2,78 \%)$ ada penurunan 4 orang siswa. Skor rata-rata keterampilan siswa pada siklus 2 adalah $(89,36 \%)$ dan pada keterampilan individu yang mendapat skor >=4 sebanyak 33 orang siswa $(91,67 \%)$, hasil ini melampaui indikator pencapaian yang ditargetkan nilai rata-rat keterampilan $70 \%$ dan individu yang mendapat skor $>=4$ ada $70 \%$

Tabel 11. Hasil Belajar Siswa Siklus 2

\begin{tabular}{lcccc}
\hline $\begin{array}{c}\text { Jumlah } \\
\text { siswa }\end{array}$ & $\begin{array}{c}\text { Nilai } \\
\text { rata-rata }\end{array}$ & $\begin{array}{c}\text { Hasil } \geq \\
\text { Nila70 }\end{array}$ & $\begin{array}{c}\text { Hasil } \\
\text { nilai } \leq \\
70\end{array}$ & $\begin{array}{c}\text { nilai yang } \\
\text { tuntas \% }\end{array}$ \\
\hline 36 & 75,00 & 34 & 2 & $94,44 \%$
\end{tabular}

Yang mendapat nilai tuntas yaitu siswa yang nilainya $>=70 \%$ sebanyak 34 orang siswa $(94,44 \%)$ dan kenaiakan 24 orang siswa, yang mendapat nilai tidak tuntas yaitu yang nilainya $<=77 \%$ sebanyak 2 orang siswa $(5.56 \%)$. Nilai rata-rata yang di peroleh siswa 75,00. Pada siklis 2 hasil pengamatan variabel penelitian peningkatan yang berarti. Presentasi ketuntasan dalam variabel angka ini sudah melampui indikator keberhasilan yaitu $70 \%$ keaktifan naik dari $60,88 \%$ menjadi $84,02 \%$ angka ini sudah melampaui indikator keberhasilan yaitu 70\%. Presentasi ketuntasan dalam variabel keterampilan naik dari 53,70\% menjadi $84,02 \%$. Angka ini sudah melampui indikator keberhasilan yaitu $70 \%$. Dan ketutasan dalam variabel hasil belajar naik dari 27,22 $\%$ menjadi $84,02 \%$. 
Sri Susilowati: Peningkatan Hasil Belajar Siswa...

Tabel 12. Hasil pengamatan siklus 2

\begin{tabular}{llccl}
\hline No & Variable & $\%$ tuntas & $\begin{array}{l}\% \text { tidak } \\
\text { tuntas }\end{array}$ & $\begin{array}{l}\text { Indikator } \\
\text { keberhasilan }\end{array}$ \\
\hline 1. & Keaktifan & $91.60 \%$ & $8,40 \%$ & $70,00 \%$ \\
2. & Keterampilan & $88,90 \%$ & $11,10 \%$ & $70,00 \%$ \\
3. & Hasil belajar & $94,44 \%$ & $5,56 \%$ & $70,00 \%$ \\
\hline
\end{tabular}

\section{Pembahasan}

Setelah diadakan pengamatan pada siklus 1 dan 2 maka dibandingkan hasil pengamatan pada siklus 1 dan 2 pada variabel-variabel yang diamati yaitu keaktifan ,keterampilan proses dan hasil belajar. Siswa yang aktif bertanya meningkat dari 13 orang siswa $(36,11 \%)$ manjadi 28 orang siswa $(77,78 \%)$ yang aktif diskusi meningkat dari 20 orang siswa $(55,60 \%)$ menjadi 30 orang siswa $(83,33 \%)$ dan yang aktif menjawab pertanyaan guru meningkat dari 10 orang siswa $(83,33 \%)$ menjadi 20 orang siswa $(75,00 \%)$. Semua siswa yang aktif mengerjakan tugas baik pada siklus 1 dan $2(100 \%)$ dan ratarata keaktifan siswa naik dari $55,60 \%$ pada siklus 1 naik menjadi $91,60 \%$. Siswa yang terampil menyiapkan tugas meningkat dari 15 orang siswa $(69,44 \%)$ menjadi 29 orang siswa $(80,60 \%)$ siswa yang terampil mengerjakan soal meningkat dari 11 orang siswa
$(30,56 \%)$ menjadi 32 (88,90\%), yang terampil memecahkan masalah meningkat dari 14 orng siswa $(38,89 \%)$ menjadi 30 orang siswa $(83,33 \%)$ yang terampil bekerja sama 25 orang siswa $(69,44 \%$ meningkat) menjadi 32 orang siswa $(88,90 \%)$, yang terampil beradaptasi dengan teman meningkat dari 23 orang siswa $(63,89)$ menjadi 36 orang siswa $(100 \%)$ dan yang terampil mengambil keputusan meningkat dari 18 orang siswa (50\%) menjadi 33 orang siswa $(91,67 \%)$. Rata-rata keterampilan proses naik dari $(53,70 \%)$ pada siklus 1 menjadi $(53,70 \%)$. Untuk hasil belajar siswa yang mendapat nilai tuntas yaitu 70 pada siklus 1 sebanyak 10 orang siswa $(27,78 \%)$ naik menjadi 34 orang siswa(94,44\%) pada siklus 2 . Hasil pengamatan pada siklus 1 dan 2 pada variabel-variabel antara lain keaktifan siswa, keterampilan bermain peran dalam tutor sebaya dan hasil belajar menunjukkan hasil sebagai berikut:

Tabel 13. Hasil Pengamtan Variabel Pada Siklus 2

\begin{tabular}{lcccc}
\hline No & variabel & Siklus 1 & Siklus 2 & $\begin{array}{c}\text { Indikator } \\
\text { keberhasilan }\end{array}$ \\
\hline 1. & Keaktifan & $55,60 \%$ & $91,60 \%$ & $70 \%$ \\
& Keterampilan & $50,00 \%$ & $88,90 \%$ & $70 \%$ \\
2. & Hasil Belajar & $27,22 \%$ & $94,44 \%$ & $70 \%$ \\
\hline
\end{tabular}


Pembahasan

Setelah catatan observasi dianalisis ternyata sudah tidak ada masalah yang timbul, secara umum dapat dikatakan tindakan yang dilakukan pada siklus II telah dapat meningkatkan aktivitas dan hasil belajar siswa dalam pembelajaran Bahasa Indonesia. Hasil belajar mengalami peningkatan yang dapat dilihat dari meningkatnya persentase jumlah siswa yang memperoleh nilai ketuntasan individu $\geq 70$. Karena persentase siswa yang memiliki kemampuan untuk memahami materi kalimat rumpang telah sesuai dengan apa yang diharapkan sehingga penelitian ini dianggap berhasil dan selesai dilakukan.

\section{SIMPULAN}

Berdasarkan pembahasan dan kesimpulan penelitian ini, dapat diketahui bahwa model pembelajaran Metode Tutor Sebaya yang diterapkan dalam pembelajaran bahasa Indonesia sangat efektif untuk meningkatkan aktivitas dan hasil belajar bahasa Indonesia siswa. Langkah-langkah kegiatan dalam model pembelajaran Metode Tutor Sebaya memungkinkan interaksi kelas tumbuh, hidup dan berkembang. Dengan penerapan model pembelajaran Metode Tutor Sebaya dapat menumbuhkan dan memberi peluang kepada siswa dalam mengembangkan dan melatih sikap serta ketrampilan sosial yang bermanfaat bagi kehidupan dan masyarakat. Dari hasil penelitian ini dapat ditunjukan bahwa respon siswa terhadap penerapan model pembelajaran Metode Tutor Sebaya dalam pembelajaran Bahasa Indonesia sangat positif. Hal ini terlihat dalam proses pembelajaran siswa lebih bersemangat dan aktif. Bahasa Indnesia merupakan pelajaran yang dianggap membosankan bagi kebanyakan siswa, oleh karena itu guru perlu menciptakan suasana belajar menyenangkan, adanya kerjasama di antara siswa, sehingga siswa termotivasi dalam belajar.

\section{DAFTAR RUJUKAN}

Arikunto, Suharsini. 1989. Prosedur Penelitian. Jakarta: Bina Aksara.

Gague, Robert 1988. Prinsip-prinsip Belajar Untuk Pengajaran di Sekolah. Surabaya: Usaha Nasional.

Gordon, Thomas. 1983. Menjadi Orang Tua Efektif. Jakarta: PT. Gramedia

Hadi, Sutrisno. 1987. Metodologi Reseach II. Yogyakarta: Yayasan Penerbit Fakultas Psikologi UGM.

Mustofa, Zainal. 1991. Prosedur Penelitian. Jakarta: CV. Persada.

S, Winkel W. 1983. Bimbingan dan Konseling di Sekolah Menengah. Jakarta: PT. Gramedia.

Slaneto. 1988. Belajar dan FaktorFaktor yang Mempengaruhinya. Jakarta: PT. Bina Aksara. 
SCHOOL EDUCATION JOURNAL VOLUME 9 NO. 2 JUNI 2019

e-ISSN': 2407-4926 